\title{
British Legal Institutions and Transaction Costs in the Early Transport Revolution
}

\author{
Dan Bogart $^{1}$ \\ Assistant Professor \\ Department of Economics \\ UCI \\ dbogart@uci.edu
}

\begin{abstract}
It is often suggested that British common law legal institutions contribute to economic development by making property rights more secure. However, strong property rights in land are not necessarily conducive to growth-enhancing investments in infrastructure because the interests of landowners and promoters can be opposed. A crucial issue is whether the legal system stifles investment by encouraging redistribution of profits in condemnation hearings. This paper examines the role of juries in implementing rights of way in Britain during the early Transport Revolution. Data from two case studies shows that some juries engaged in significant redistribution. A simulation analysis shows that jury redistribution had a deterrence effect for projects at the margins of profitability. The findings have implications for a broader interpretation of institutions, investment, and British economic growth during the eighteenth and nineteenth century.
\end{abstract}

Key Words: Legal Systems, Common Law, Transport Revolution, Institutions

\footnotetext{
${ }^{1}$ I would like to thank Stegrios Skepardis, Michelle Garfinkel, Debin Ma, and Jan Luiten Van Zanden for comments on earlier drafts.
} 


\section{Introduction}

For centuries scholars have been trying to identify which features of legal systems are crucial to economic activity. Recently the Legal Origins School has posited that some legal systems contribute to different degrees of transaction costs and hence different levels of trade, investment, and innovation. The Common Law legal system is often singled out because it is believed to provide strong protection for property rights. ${ }^{2}$ According to the standard narrative, British landowners could invest in their property with little fear of government expropriation or judicial activism. Laws and norms protecting rights to land were eventually extended to contractual arrangements in finance following the political transformations of the seventeenth century (North and Weingast 1989; Neal 1990). In the long-run, Britain succeeded economically, so the argument goes, because its legal system was conducive to development.

The Legal Origins view may be helpful in explaining Britain’s precocious leadership in agriculture and finance, but it is not an obvious fit in the infrastructure sector. ${ }^{3}$ Infrastructure projects often pit landowners against promoters because land is an input into infrastructure investment. In most societies, the legal system has to choose between the rights of landowners and promoters when determining compensation for land taken or damaged. Given that Britain's legal system has traditionally provided strong property rights to land, it is not clear that courts would be friendly to infrastructure promoters in condemnation proceedings. The link between British legal institutions and infrastructure has broader implications. There is a growing body of

\footnotetext{
${ }^{2}$ For a sample of works in this large literature see Hayek (1960), Mahoney (2001), La Porta et. al. (2004), and Klerman and Mahoney (2007).

${ }^{3}$ One could also argue that the common law was not necessarily conducive to manufacturing because of restrictions on business organization. See Harris (2000) for a discussion of these points.
} 
scholarship showing that transport improvements were a key driver of economic development in Britain. ${ }^{4}$ Hence legal deterrents to infrastructure investment could affect the economy greatly. This paper examines the role of juries in implementing rights of way in Britain during the early Transport Revolution. Juries have a long history in criminal trials, but their role in civil litigation, specifically condemnation proceedings, is more nuanced. In the seventeenth century, commissions composed of large landowners were given the authority to determine compensation for infrastructure projects. There was a shift following the Glorious Revolution of 1688-89 in that Parliamentary acts began giving juries composed of small and large landowners the authority to recommend compensation. The role of juries increased in the eighteenth and nineteenth centuries as they were called to determine compensation for thousands of road, river, canal, and railway projects.

Relatively few studies have analyzed the behavior of juries with respect to condemnation proceedings in Britain's industrializing era. Kostal (1994) argues that railway companies in the 1830s and 40s were concerned that jury members would be biased to their fellow landowners and would award large compensation. On the other hand, landowners were also concerned that juries would be biased to the railways because jury members had invested in railway securities. Pollins (1952) investigates the implications of juries for railway investment costs. The data indicate that land purchases represented $14 \%$ of investment costs on average, suggesting that juries could affect profitability.

This paper investigates whether juries engaged in substantial redistribution and whether they affected investment promotion in eighteenth century river navigation projects. It first develops a theoretical framework to study how juries determined compensation. The theory highlights the role of jury bias and shows that it affects compensation payments. The analysis also highlights

\footnotetext{
${ }^{4}$ See Bogart (2005) and Leung (2006) for recent evidence on the effects of transport improvements.
} 
the link between bias and investment incentives. Once a promoter has initiated a project the jury can redistribute most of the surplus to the landowner leaving an insufficient amount to cover their sunk costs. As a result, if the promoter anticipates that the jury is biased and will redistribute most of the profits to the landowner they will not initiate the project to begin with.

The behavior of juries is investigated empirically with two cases studies involving the Aire and Dun river navigation projects. The evidence shows that juries awarded landowners compensation well above the market value of land. The premiums ranged from $50 \%$ of the value to as much as $270 \%$. The evidence also implies that if the market value was awarded, investment costs would have been lowered by at least $2.5 \%$ and as much as $12 \%$.

Next the analysis investigates whether jury premiums significantly affected investment incentives. A simulation analysis shows that internal rates of return would have increased by around $0.2 \%$ if juries engaged in no redistribution. It also shows that some navigation projects below the $50^{\text {th }}$ percentile in terms of toll revenues would have switched from being marginally unprofitable to marginally profitable if juries engaged in no redistribution. The implication is that jury behavior could have a non-negligible impact on total investment.

This paper fits into is a larger thesis which can be summarized in the following scheme: Legal and political institutions $\Rightarrow$ transaction costs $\Rightarrow$ infrastructure investment. It contends that the evolution of British legal and political institutions in the seventeenth and eighteenth century greatly influenced the cost of obtaining, implementing, and enforcing investment rights. Promoters obtained their rights through acts or patents granted by Parliament and the King. Government authorization engendered uncertainty because Parliament or the King could eliminate rights through edicts or the passage of an act. Moreover, promoters had to pay fees, hire agents, and negotiate with politicians to get their act or patent approved. After obtaining 
rights promoters faced additional challenges. Local groups could sue for damages to their property or business and might obtain sizeable damages from juries.

The impact of transaction costs appears to have changed following the Glorious Revolution, as indicated by the dramatic increase in transport investment after the mid 1690s (Bogart 2009). The evidence suggests that the Glorious Revolution mattered in part because conflict between the Crown and Parliament was lessened and Parliament gained greater regulatory control. The shift to juries following the Glorious Revolution had a more complex effect on investment incentives as this paper illuminates.

The findings also fit into a broader literature on juries and their economic effects. It is often noted that most US corporations are established in Delaware because its main civil court does not have jury. The implication which is often drawn is that juries are a hindrance to secure property rights and hence economic development (Roe 2007). British juries could be viewed from this perspective, but it is important to note that they offered other benefits. Compensation was awarded quickly, often with a few months instead of years as in France before the French Revolution (Rosenthal 1992). Also juries gave landowners and other property-owners assurances that their rights would not be trampled upon. Thus they could invest with little fear that their income rights would be violated by an egregious jury in the future.

\section{Background on Infrastructure promotion and implementation in Britain}

The limitations of Britain's internal transport system became a problem in the seventeenth century as its economy began a long period of ascent. The Stuart monarchy which prevailed in the early 1600 s was unwilling or unable to undertake investments. Instead it enabled individuals 
or local communities to initiate projects. Promoters sought various types of enabling rights including patents and acts, but few were successful.

Political turmoil greatly impacted infrastructure promotion. Both the Crown and Parliament sought to control the supply of rights, sometimes at the expense of the other. Their ability to exert control fluctuated with political changes like the Era of Personal Rule (1629-1640), the period of Civil War (1641-49), and the Restoration era (1661-69). The Glorious Revolution of 1688-89 finally settled the issue of regulatory authority. After 1689 all promoters turned to Parliament for rights first. King William and his successors to the throne ratified Parliamentary bills supplying rights, but were not instrumental in the process.

Infrastructure bills were first submitted to the Commons and then approved by the Lords and eventually the King. There were no formal 'barriers' to submitting bills. Essentially any individual or community could submit a petition. For example, in 1725 the Master, Wardens, Searchers, Assistants, and Commonality of the Corporation of Cutlers in Hallamshire petitioned to improve navigation on the river Dun. In their petition they state:

Making the River Dun navigable from...Doncaster...to... within two miles of Sheffield will be advantageous not only to the said corporation but also to the public in general by preserving the roads and by a cheap conveyance of commodities to and from London. ${ }^{5}$

Once submitted, a private bill committee heard evidence from witnesses and petitions from groups opposed to the bill. The committee then made a recommendation to the entire House of Commons or Lords. Committee proceedings often determined the success or failure of a bill (Hoppit 1997).

There were costs associated with getting a parliamentary bill passed. Promoters had to pay a schedule of fees dictated by legislative procedures in the House of Commons and Lords known as Standing Orders. In general, the further the bill went in the process, the more the total fee

\footnotetext{
${ }^{5}$ See the Journals of the House of Commons, 11.3.1725.
} 
increased. The fees were paid to various officers of the House who performed services like handling the bill or engrossing the bill on parchment. MPs and Peers did not directly receive these fees.

Promoters also hired parliamentary agents or solicitors to advance their bill. The agents played an important role because they organized witnesses, ensured bills did not fail for technical reasons (i.e. violations of standing orders), and helped persuade MPs and Peers of the merits. Agent fees could be the most substantial expense in obtaining rights, sometimes exceeding $80 \%$ of the total cost. For example, the solicitors, Messrs. Wilkinson \& Frost, charged the promoters of the Hull and Hedon roads bill $£ 494$ in 1832. The average fee collected by officers in the Commons in the same year was around $£ 100 .^{6}$

Once a promoter obtained an improvement act they faced the difficult task of implementing the project. One of the most challenging hurdles involved negotiations with property-owners for the purchase of land and property. These negotiations were crucial because many infrastructure projects could not be completed without the land input. The negotiations were complicated because particular pieces of land were often necessary to widen rivers or roads or to construct a canal or railway.

The provisions of parliamentary acts typically contained clauses determining how property owners would be compensated for lands taken or damaged. In the early 1600s, patents and acts named a body of commissioners who had authority to award compensation if landowners and promoters could not agree privately. Commissions could be unpopular and there were cases where they appear to have been biased. For example, a commission appointed by the Crown in

\footnotetext{
${ }^{6}$ For more details see the survey of the bills charged by Parliamentary agents in 1820s and 1830s (BPP 1833 XII, pp. 248-251). The report also lists the average fees collected on various bills in the House of Commons in 1832.
} 
1638 recommended that the promoter for the river Lark should pay landowners $£ 40$ per acre. $^{7}$

The market value for land in the early seventeenth century was around $£ 10$ per acre or one-fourth the compensation recommended by the commission. ${ }^{8}$

After 1689 the rules for compensating landowners changed. Increasingly commissioners were required to impanel juries if promoters and landowners could not agree. In 11 river navigation acts from 1661 to 1688 only one included a jury provision. ${ }^{9}$ However, in the 16 river navigation acts from 1690 to 1714, eight stated that juries must advise and recommend compensation. The trend continued after 1715 with nearly all road improvement and river navigation empowering juries.

The minute books for a number of commissions and juries have survived and provide insights into their behavior. I briefly review these sources for a jury that was impaneled to determine compensation for the Aire and Calder river navigation. The Aire was authorized to be made navigable from Leeds to Ferrybridge by an act in 1699. It was promoted by merchants in the nearby woolen textile town of Leeds who later became the undertakers for the Aire and Calder navigation company. They were known locally as the 'fourth estate of the realm' because they were enriched by the substantial profits from the navigation (Wilson 1971, p. 140).

The Aire and Calder act named body of nearly 100 commissioners which included members of the nobility, gentry, and other classes. ${ }^{10}$ The act also included a clause which stated that the

\footnotetext{
${ }^{7}$ Willan, River Navigation, pp.27-28.

${ }^{8}$ The prices of land in Suffolk, near the river Lark, are taken from the Charity Commission records (Clark 1998). These will be discussed later in the paper.

${ }^{9}$ See the Parliamentary Archives for copies of all river navigation acts. Some acts relating to road and river improvements before 1714 are available in the Statutes of the Realm, but most require archival sources.

${ }^{10}$ See William III, 1698: An Act for the makeing and keeping navigable the Rivers of Aire and Calder in the County of Yorke. [Chapter XXV. Rot. Parl. 10 Gul. III. p. 4. n. 10]', Statutes of the Realm: volume 7: 1695-1701 (1820), pp. 534-538. URL: http://www.british-history.ac.uk/report.aspx?compid=46958. Date accessed: 18 February 2010.
} 
jury was to 'inquire and assess damages upon oath; the Commissioners were to give judgment accordingly by examinations on oath and determine all controversies touching the said matters.'

The commissioner minute books describe the condemnation proceedings. ${ }^{11}$ The first entry in September of 1699 states that the undertakers came to an agreement with Charles Robinson for the sale of a dam and lock near Fleet Mills. The sale of Robinson's land was approved by seven commissioners in the same month. The second entry in October 1699 states that a jury was impaneled and issued a verdict on the value of land. The jury included 12 men described as 'able and sufficient men of the county of Yorkshire.' None appear to be members of the nobility. The commission ordered the undertakers to award the compensation recommended by the jury. Additional entries in 1700 and 1702 describe similar verdicts by the jury and commissioners' approval.

From this case it is clear that juries could play a pivotal role in determining compensation for infrastructure projects. There is similar evidence that jury's determined compensation for the Dun river navigation project in the 1730s. Later I will compare the compensation awarded by the juries for the Aire and Calder and the Dun navigations with the market value of land in Yorkshire where these two projects were located. First, the following section provides an analytical framework for studying juries.

\section{A Model of Jury Compensation and Infrastructure Promotion}

Jury behavior has been modeled from a number of perspectives, but there is little theoretical work on the relationship between jury decision making and investment decisions ${ }^{12}$. This section combines a model of jury behavior and infrastructure promotion. It illustrates how jury bias

\footnotetext{
${ }^{11}$ See the National Archive RAIL 800/1.

${ }^{12}$ There are some recent works addressing judicial agency from a contract theory perspective. See Bond (2009) for one example.
} 
influences compensation awards and hence the incentive to invest. The model is based on a stage game involving promoters and juries. The stages and payoffs are described in figure 1.

Figure 1: Stage Game

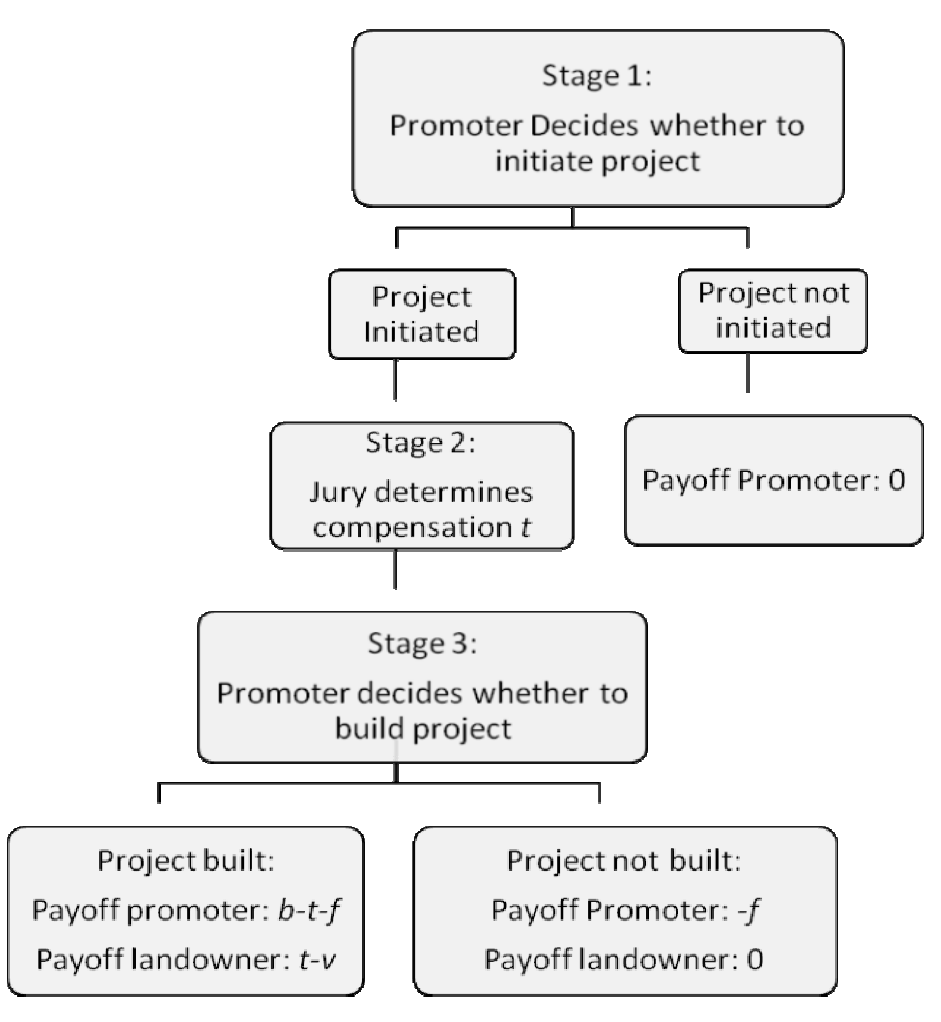

In stage 1, the promoter decides whether to initiate the project. If the promoter does not initiate then they receive a payoff of zero and the game ends. If the promoter initiates they must immediately pay private bill fees $f$. Private bill fees are a 'sunk' cost: once paid they cannot be recovered. Private bill fees are assumed to be exogenous for the purposes of this paper, but they can be endogenously determined in an extension of the model. ${ }^{13}$

\footnotetext{
${ }^{13}$ Private bill fees were partly determined by the degree of opposition to a bill. More opposition meant greater expenditures on parliamentary agents, identifying witnesses, influencing MPs, etc. The interaction between opposition and promoters could influence jury deliberations and vice versa but this is not explored here.
} 
In stage 2 the jury must determine a compensation award $t$ to the landowner. The jury awards compensation based on its own utility function which weighs the utilities of the landowner and promoter. It is worth noting at this point that the jury cannot commit to any compensation award. In particular it cannot guarantee positive profits for the promoter at the initiation stage.

In stage 3 the promoter decides whether to build the project. Once this decision is made the compensation payment is made and the payoffs are realized. If the project is built the payoff to the promoter is $b-t-f$, where $b$ is the net present value of the project not including the compensation award and private bill fees. The payoff to the landowner is $t-v$ where $v$ is the market value of the land in its normal use. If the project is not built then it is assumed that the promoter does not compensate the landowners because their land is not taken or damaged. The payoff to the promoter is $-f$ if the project is not built. Throughout we assume that $b-f-v>0$ which implies the project has social as well as private value.

The equilibrium is a triplet $\{I, t, B\}$ where $I \in\{0,1\}$ is an indicator taking the value 1 if the promoter initiates; $t \in(0, \infty)$ is the transfer payment awarded by the jury; $B \in\{0,1\}$ is an indicator taking the value 1 if the promoter builds. There are two types of equilibrium. In the first, projects are initiated and built and the transfer $t$ is less than $b-f$. In the second, projects are not initiated and therefore not built. The second equilibrium is inefficient and arises because of jury bias.

The equilibrium are identified using backward induction beginning with the build decision in stage 3 and working backwards to the compensation and promotion decisions in stages 2 and 1. Suppose first that the promoter has initiated the project in stage 1 and the jury has made a compensation award $t$ to landowners in stage 2 . In stage 3 , the promoter's decision 
whether to build is straightforward. If the payoff from building the project $b-t-f$ is greater than the payoff from not building $-f$ then the promoter builds. Simplifying this expression implies the project is built if $b \geq t$. Notice that the private bill fee $f$ is irrelevant to decision making at this point in the game because it was paid in stage 1 . Notice also that the promoter does not necessarily earn a positive payoff from building. $b-t-f$ could be less than zero because the transfer is close to $b$, but building is still worthwhile because the losses are less than scrapping the project and suffering a loss of $-f$.

Next consider the jury's decision to award compensation in stage 2 assuming that in stage 1 the promoter has initiated the project. The jury knows the promoter will build the project in stage 3 if they award a transfer $t$ less than $b$. I assume the jury wants the project to be built because they can redistribute some of the surplus to the landowner. The jury is assumed to have a utility function $\theta U_{l}(t-v)+(1-\theta) U_{p}(b-t)$ which weighs the utilities of the promoter and the landowner. $U_{p}$ and $U_{l}$ are the jury's utility functions for the promoter and the landowner. The parameter $\theta$ can be interpreted as the jury's bias to the landowner. A value of $\theta$ close to 1 represents greater favoritism to the landowner. A value of of $\theta$ close to 0 represents greater favoritism to the promoter. Notice that the jury does not consider the total payoff to the promoter: $b-t-f$. This reflects the notion that the jury cannot commit to give the promoter a positive surplus once they have initiated and paid private bill fess $f$.

The jury's problem is the following:

$$
\max _{t}: \theta U_{l}(t-v)+(1-\theta) U_{p}(b-t) \text { such that } 0 \leq t \leq b
$$

There are three possible cases for the equilibrium transfer $t^{*}$. First, the jury could set $t^{*}$ equal to the value $b$ effectively transferring all surplus to the landowner. Second the jury could 
set $t^{*}$ equal to 0 effectively expropriating all value from the landowner. Third, the jury could set $t^{*}$ between 0 and $b$ splitting the surplus between the promoter and landowner. In the third case, the transfer $t^{*}$ will satisfy the following equation:

(1) $\quad \frac{\theta}{1-\theta}=\frac{-\partial U_{p}(b-t)}{\partial t}\left(\frac{\partial U_{l}(t-v)}{\partial t}\right)^{-1}$

A solution to (1) is guaranteed as long as the utility functions are increasing and concave in payoffs. Using the concavity property, one can show that a higher $\theta$ corresponds to a higher transfer payment $t^{*} \cdot{ }^{14}$

The jury's behavior can be illustrated in the case of a natural log utility function $U_{l}=U_{P}=\log (\bullet)$. The equilibrium transfer is given by the expression: $t^{*}=\theta b+(1-\theta) v$. As the jury becomes more biased to the landowner and $\theta$ approaches 1 then the transfer approaches the value of the project $b$. As the jury becomes less biased to the landowner and $\theta$ approaches 0 the transfer approaches the value of the land $v$. Later it will be useful to analyze the percentage difference between the transfer and the value of the land (i.e. the premium earned by the land owner) measured by the ratio: $\left(t^{*}-v\right) / v$. Notice that the premium is increasing in jury bias.

In stage 1 the promoter decides whether to initiate the project anticipating the transfer payment the jury will award to the landowner in stage 2 and their build decision in stage 3 . The promoter knows that their payoff is $b-t^{*}-f$ if they initiate and 0 if not. Thus the promoter will initiate only if $t^{*}<b-f$. In other words if the promoter knows that the jury will set a

${ }^{14}$ By concavity $\frac{\partial U_{p}(b-t)}{\partial t}$ increases as $t$ gets larger and $\frac{\partial U_{l}(t-v)}{\partial t}$ gets smaller as $t$ gets larger. Thus by equation (1) $t$ must increase if $\theta$ increases. 
transfer $t^{*}$ close to the value of the project $b$ then the promoter will not initiate since they will not earn a sufficient return to justify the payment of private bill fees $f$.

Given that the transfer $t^{*}$ is increasing in the degree of jury bias to the landowner, it follows that the promoter is less likely to initiate if $\theta$ is close to 1 . In the case with natural $\log$ utilities the condition for the promoter to initiate is $\theta<\frac{b-v-f}{b-v}$. This example also illustrates how the value of the project is crucial. If the jury is not completely biased to the landowner (i.e. $\theta<1$ ) then the promoter will initiate for a sufficiently large $b$. Figure 2 shows the range of values for $b$ and $\theta$ where promotion occurs assuming $v$ and $f$ equal 1 . For sufficiently large values of $b$ or sufficiently small values of $\theta$ promotion will occur.

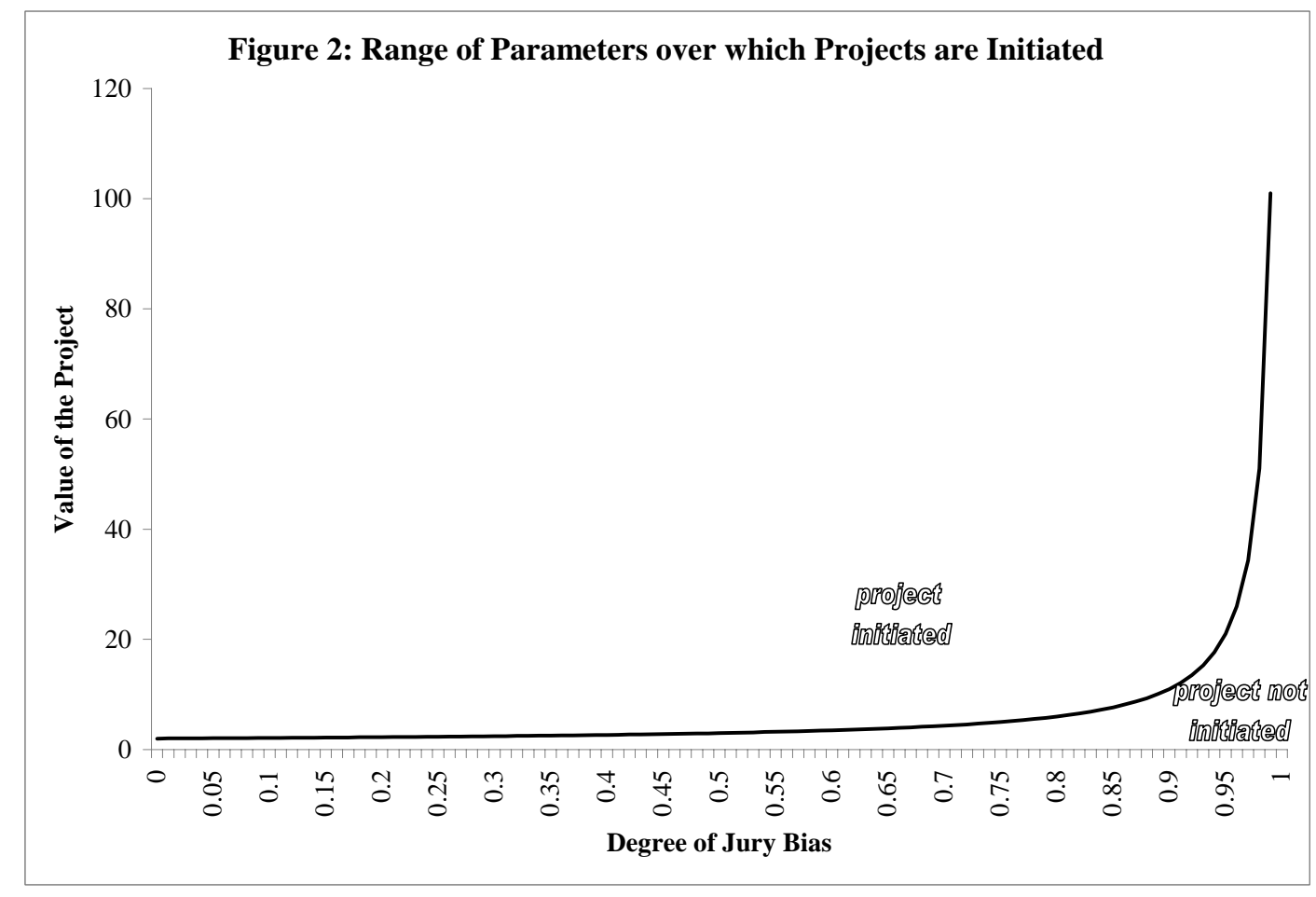

As a final remark it is important to emphasize the jury's inability to commit to give the promoter a positive payoff once it has initiated the project. If the jury could commit then it would promise never to award a transfer larger than $b-f$ which is the condition for positive payoffs at 
the initiation stage. Redistribution from the promoter to the landowner could still occur but it would not preclude investments with positive social value (i.e. $b-f-v>0$ ).

\section{Empirical Analysis of Jury Redistribution and Investment}

The theoretical framework illustrates how juries had the potential to redistribute profits to landowners and potentially undermine the incentives to invest in infrastructure. This section investigates these issues empirically for river navigation projects in the eighteenth century. Jury decisions were recorded in minute books which list the compensation awarded to each landowner. In this section, I use the jury minute books for the Aire and Calder river navigation and the Dun river navigation to investigate how juries compensated landowners.

The minute book for the Aire jury shows that the degree of compensation varied across a total of 95 landowners. ${ }^{15}$ Two received $£ 50$ per acre as compensation; twelve received $£ 40$ per acre; and eighty-one received $£ 15$ per acre. Some of the landowners in the latter group held land subject to common rights or at a greater distance from Leeds which partly explains the lower compensation. Across all plots the average compensation was £19 per acre.

These payments can be compared with the average price of land in Yorkshire where the Aire was located. The charity commission records compiled by Greg Clark (1998) provide a sample of land transactions for charities from the 1600s to the 1900s. The data show that the average price across 50 transactions between 1680 and 1720 was $£ 12.6$ per acre and the standard deviation is 8.5. I use this sample to test whether the average land value in the Charity data between 1680 and 1720 was statistically different from the average compensation awarded by the Aire jury. The test statistic for a difference in means is 15.03 with a p-value close to 0 . The

\footnotetext{
${ }^{15}$ See the National Archive RAIL 800/1.
} 
ratio of the average compensation awarded to the average market value was $1.5(=19 / 12.6)$. This suggests that the jury for the Aire river project awarded a 50\% premium to landowners.

A 50\% premium is substantial but it does not necessarily follow that total investment costs were substantially affected because land was only one input in construction. The Aire navigation company raised a total of $£ 26,700$ for construction including compensation to landowners (Wilson 1971). ${ }^{16}$ The jury minute books do not indicate the total area taken and thus the total amount paid for land. However, it is likely that navigation companies purchased an acre of land or less because their activities were confined to widening or making new cuts in the river. Therefore, one can assume without too much error that promoters purchased one acre from each plot listed in the jury minute book. The implied total compensation would be $£ 1795$ or $7 \%$ of the total investment cost. This implies that if the jury gave landowners the market value in Yorkshire around 1700 then total compensation would have decreased to $£ 1189$ which represents a $2.5 \%$ decrease in total investment costs.

A similar comparison is made for the Dun navigation project. The Dun navigation was authorized by a series of acts in the late 1720s. It was promoted by the Corporation of Doncaster and merchants in the metal-working districts near Sheffield in Yorkshire. The Dun is also unique because it was one of the first joint stock transport companies. A jury was impaneled in 1729 to determine compensation for landowners near the Dun. Over a five year period the jury awarded compensation on 83 plots. ${ }^{17}$ The price varied between a minimum of $£ 10$ per acre and a maximum of $£ 600$ per acre. Figure 3 plots the distribution of compensation awards per acre across the 83 plots. Most of the awards were less than $£ 70$ but some exceeded this amount. Across all landowners the average compensation was $£ 52$ per acre.

\footnotetext{
${ }^{16}$ It was typical in accounting practices at the time to regard compensation payments and private bill fees as investment costs.

${ }^{17}$ See the National Archive RAIL 825/7.
} 


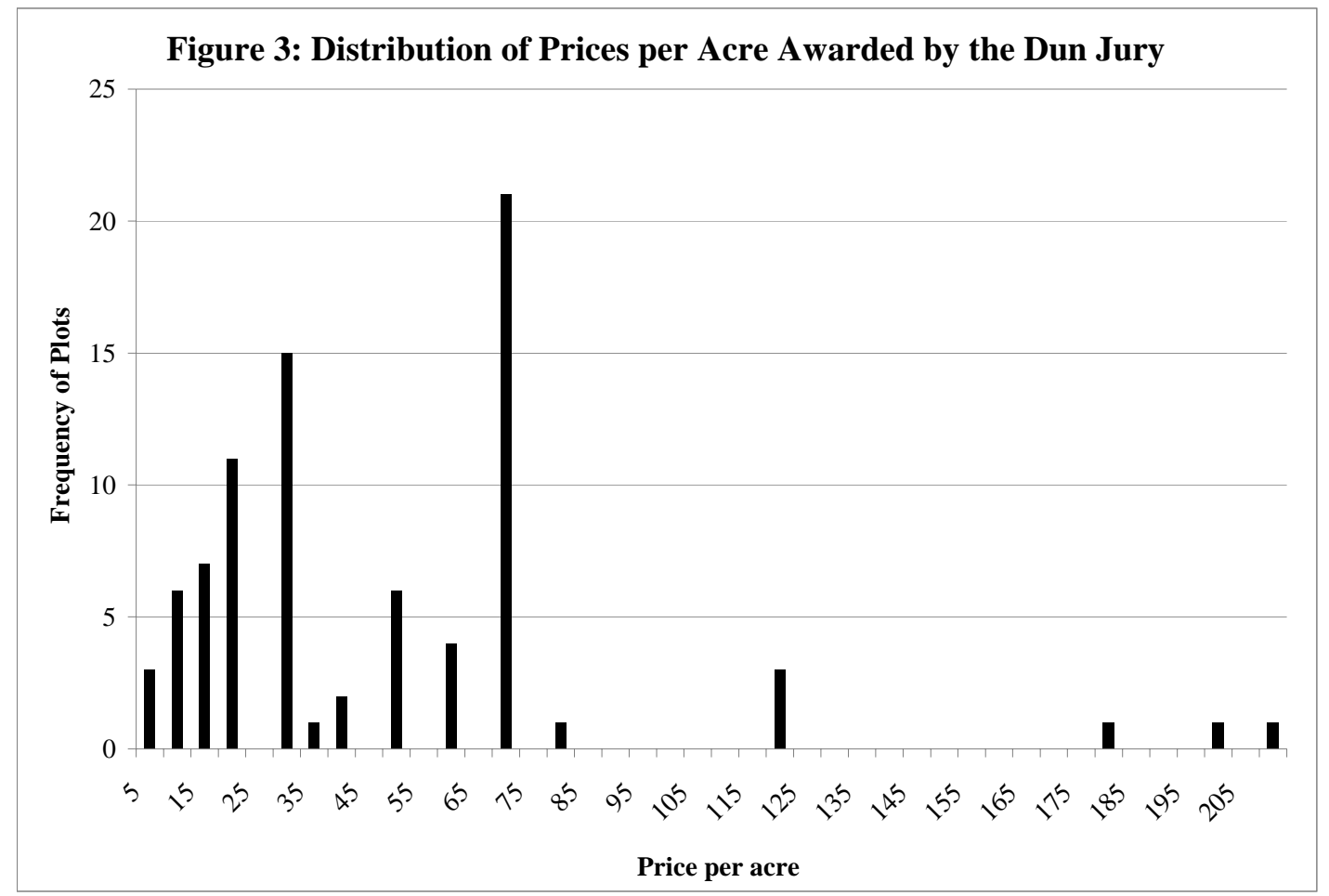

The Charity data show that the average price across 59 transactions in Yorkshire between 1710 and 1750 was $£ 13.8$ per acre and the standard deviation is 10.3. Like before, we can reject the hypothesis that the average market value is the same as the average compensation awarded by the Dun jury. The test statistic for the difference in means between the two samples is 4.47 with a p-value close to zero. Taking the average value for the compensation to be $£ 52$ per acre implies that the Dun awarded a 270\% premium to landowners. The premium is still large if outliers are dropped. Without compensation awards above $£ 100$, the average is $£ 38$ per acre or 175\% more than the market value of land.

Based on these figures, the Dun jury appears to have been more redistributive than the Aire jury. The compensation awarded by the Dun jury also had a greater effect on total investment costs. Willan (1964) states the Dun company raised £24,750 for construction. Assuming the company purchased one acre from all the landowners listed in the jury minute books implies a total compensation of $£ 4298$ or $17 \%$ of the total investment cost. If the Dun jury 
gave landowners the market value in Yorkshire around 1730 then compensation would have fallen to $£ 1140$ which would represent a $12 \%$ decrease in total investment costs.

Overall these two cases suggest that investment costs could be affected if a jury engaged in substantial redistribution. The remaining issue is whether the observed redistribution patterns significantly affect investment promotion. According to the model, investment promotion occurs when the value of the project is greater than private bill fees and expected compensation payments. In practical terms, this meant that a project had to have sufficiently high operating profits or sufficiently low investment costs net of compensation payments and private bill fees. The proportion of projects which met this criterion can be characterized using simulation analysis and information on the distribution of operating profits and investment costs. Table 1 summarizes the frequency of toll income per mile in 1750 and investment cost per mile for a sample of projects. The toll income provides a reasonable proxy for operating profits because toll collection costs were already deducted and maintenance costs for river navigations were small (Willan 1964).

Table 1: Distribution of Investment Costs and toll income per mile for a sample of projects Investment cost per mile frequency toll income per mile 1750 Frequency

\begin{tabular}{cccc}
$0-499$ & 1 & $25-50$ & 1 \\
$500-999$ & 4 & $51-75$ & 4 \\
$1000-1499$ & 4 & $76-100$ & 3 \\
$1500-1999$ & 0 & $101-125$ & 1 \\
$2000-2499$ & 1 & $126-150$ & 0 \\
$2500-2999$ & 0 & $151-175$ & 1 \\
$3000-3499$ & 0 & $176-200$ & 1 \\
$>3500$ & 2 & $>200$ & 1 \\
\hline
\end{tabular}

Sources: see Appendix. 
The toll income and investment cost data are used to simulate the internal rate of return for projects at different percentiles of the distribution. The internal rate of return is equivalent to the interest rate at which a project's net present value is zero. The net present value is given by the formula: $\sum_{t=0}^{\infty} \frac{\text { toll }_{t}-k_{t}}{(1+r)^{t}}$ where $r$ is the interest rate, toll $t_{t}$ is the toll income in year $t$, and $k_{t}$ is the investment cost in year $t$. In all the calculations, investment costs are spread evenly over ten years and the annual rate of growth in tolls is $1.6 \%$ from 1700 to 1830 . The base values for investment costs and toll income in 1750 are taken from table $1 .^{18}$

Panel A in table 2 summarizes the internal rate of return for the $25^{\text {th }}$ and $75^{\text {th }}$ percentile of toll income and investment costs reported in table 1 . The interest rate on government debt was around 5\% in the early eighteenth century. Therefore, I use 5\% as the threshold rate of return for a river navigation project to be initiated. In the baseline scenario, projects in the bottom quartile of toll income and the upper quartile of investment costs would not be initiated because they earned a return below 3.5\%. Projects above the $50^{\text {th }}$ percentile in toll revenues and below the $50^{\text {th }}$ percentile in investment costs would be initiated because they earned a return in excess of $5.9 \%$. Projects within the $25^{\text {th }}$ and $50^{\text {th }}$ percentile for toll revenues and projects within the $50^{\text {th }}$ and $75^{\text {th }}$ percentile for investment costs earned around $4.9 \%$ and $4.1 \%$. In other words they were below or at the margin of profitability.

\footnotetext{
${ }^{18}$ See the appendix for details.
} 
Table 2: Simulation of Internal Rates of Return for river navigation projects

\begin{tabular}{|c|c|c|}
\hline & \multicolumn{2}{|c|}{ Panel A: Baseline } \\
\hline & 50th PCTL investment cost & 75th PCTL investment cost \\
\hline 25th PCTL toll income & 4.9 & 3.5 \\
\hline \multirow[t]{3}{*}{ 50th PCTL toll income } & 5.9 & 4.1 \\
\hline & \multicolumn{2}{|c|}{ Panel B: Counter-factual with Lower jury redistribution } \\
\hline & 50th PCTL investment cost & 75th PCTL investment cost \\
\hline 25th PCTL toll income & 5.2 & 3.7 \\
\hline 50th PCTL toll income & 6.3 & 4.3 \\
\hline
\end{tabular}

Sources: see text.

Now consider the counterfactual where juries engaged in no redistribution and awarded landowners the market value for their land. The earlier evidence suggests that had the Aire and Dun juries awarded the market value, then investment costs would have declined by between 2.5 and $12 \%$. For the purposes of the counter-factual I consider the case where lowering jury premiums would reduce investment costs by $7 \%$ at all points of the investment cost distribution. The rates of return in this case are reported in panel B of table 2. Not surprisingly the rates of return are all higher, increasing by 0.2 to $0.3 \%$. More importantly, the rate of return for the project in the $25^{\text {th }}$ percentile of toll revenues and the $50^{\text {th }}$ percentile of investment costs is now $5.2 \%$ and above the threshold for project initiation. The implication is that jury redistribution may have discouraged some projects in the second quartile of the distribution of toll revenues.

\section{Conclusion}

Juries played a pivotal role in condemnation proceedings for infrastructure projects in the eighteenth and nineteenth centuries. They had the power to redistribute profits from promoters to landowners and in theory they could deter promoters from initiating projects. Drawing on the 
cases analyzed in this paper it appears that some juries engaged in substantial redistribution. There is also evidence that the threat of redistribution deterred the promotion of projects at the marginal of profitability. Overall it appears that juries might have been a hindrance to infrastructure investment in Britain. These findings remain tentative because more studies on jury redistribution are needed. Secondly, there may have been benefits from juries, such as expedited dispute resolution, that are not captured by the model described in section III. It is also worth noting that transportation facilities are natural monopolies and thus the owners can earn substantial rents from receiving rights-of-way. Juries might have helped to spread some of the wealth to small and medium sized landholders.

Juries also need to be placed in the context of other institutional changes which emerged in the post-Glorious Revolution period. There were substantial transaction costs associated with infrastructure promotion in the 1600s and early 1700s. There was a risk of government manipulation of improvement rights in the 1600s because of frequent political changes associated with the conflict between Crown and Parliament. Several undertakers had their rights violated following the Civil War and the Restoration. After the Glorious Revolution improvement rights became more secure. Only a small fraction of undertakers obtaining rights between 1689 and 1750 suffered violations. The greater stability of the political regime in the eighteenth century contributed to a lower risk of government manipulation and ultimately encouraged investment. Other institutional changes involving negotiations between promoters, opposition groups, sponsoring MPs, parliamentary committees, and party leaders were of crucial importance as well. Future research will reveal how these other institutional changes mattered along with juries. 


\section{Appendix}

Table 3 shows the average toll income per mile for various rivers using data on toll leases. The sample consists of river navigations covering 175 miles which is more than $35 \%$ of the total made navigable by 1750 . Some of the observations come from 1750 while others come from the 1720s, 1730s, and 1740s. It is necessary to extrapolate the toll income to 1750 to estimate the distribution of toll income in 1750. Detailed data on the Aire shows that the average annual growth rate from 1740 to 1750 is $3.7 \%$. Extrapolating toll income to 1750 using this growth rate yields the estimates of average toll income per mile in the last column.

Table 3: Toll Income per Mile on river navigations (net of collections costs)

\begin{tabular}{lccccc}
\hline \hline River & $\begin{array}{c}\text { Time } \\
\text { period }\end{array}$ & $\begin{array}{c}\text { Annual toll } \\
\text { income } \\
\text { (in £) }\end{array}$ & Miles & $\begin{array}{c}\text { Estimated toll } \\
\text { income, 1750 } \\
\text { (in £) }\end{array}$ & $\begin{array}{c}\text { Estimated toll income } \\
\text { per mile, 1750 } \\
\text { (in £) }\end{array}$ \\
\hline Aire & & & & & \\
Kennet & 1750 & 4400 & 25 & 4400 & 176 \\
Beverly beck & $1720 \mathrm{~s}$ & 667 & 20 & 1312 & 66 \\
Tone & $1730 \mathrm{~s}$ & 99 & 0.75 & 130 & 173 \\
Yorkshire ouse & $1720 \mathrm{~s}$ & 386 & 11 & 813 & 74 \\
Weaver and Dane & 1732 & 600 & 18 & 1104 & 61 \\
Dun & $1730 \mathrm{~s}$ & 1674 & 20 & 2271 & 114 \\
Wear & 1740 & 1500 & 18 & 193 & 83 \\
Great Ouse & 1732 & 1200 & 11 & 2208 & 221 \\
Cam & 1750 & 1784 & 23 & 1784 & 61 \\
Lark & 1750 & 430 & 7 & 430 & 31 \\
Dee & 1742 & 332 & 14 & 435 & 98 \\
& 1740 & 556 & 8 & 780 & 103 \\
Average & & & & & \\
& & 1136 & 15 & 1322 & \\
\hline
\end{tabular}

Sources: For the Aire and Calder, Kennet, Beverley Beck, Tone, Yorkshire Ouse, Weaver and Dane, and Dun rivers see Willan (1964, pp. 124-130) For the Great Ouse, Cam, and Lark see Summers (1973, pp. 150, 226-28). For the Wear and Dee see JHC, 6.2.1732 and 5.3.1743. The mileage of rivers is taken from Priestly (1969) and Shead (2007).

The annual growth rate of toll income must also be estimated for the rate of return simulation. The data indicate that toll income for the Great Ouse navigation grew at 1.3\% per 
year before 1750 but was stagnant in real terms after 1750 . Toll income for the river Dun grew by $2.2 \%$ in the 1740 s. Toll income for the Cam grew by $0.4 \%$ from 1750 to 1813 . Toll income for the Aire grew by 3\% per year from 1700 to $1750,3.3 \%$ from 1750 to 1772, and 1.3\% from 1775 to 1827 . The rate of return calculation assumes an average annual growth rate of $1.6 \%$.

Secondary sources and the journal of the House of Commons provide information on total investment for a sample of river navigations. The sample of projects covers 187 miles or nearly $40 \%$ of the total made navigable by 1750 . The price level was fairly stable over this period, so there is no need to correct for inflation.

Table 4: Investment by River Navigations, 1600-1750

\begin{tabular}{lcccc}
\hline \hline River & $\begin{array}{c}\text { Time } \\
\text { period }\end{array}$ & $\begin{array}{c}\text { Amount } \\
\text { Invested } \\
(£)\end{array}$ & Miles & $\begin{array}{c}\text { Investment per } \\
\text { mile } \\
(£)\end{array}$ \\
\hline Avon & & & & \\
Kennet & $1640 \mathrm{~s}$ & 30000 & 42 & 714 \\
Weaver & $1720 \mathrm{~s}$ & 44603 & 20 & 2230 \\
Douglas & $1720 \mathrm{~s}$ & 18000 & 20 & 900 \\
Wey & $1720 \mathrm{~s}$ & 6000 & 17.5 & 343 \\
Salwerpe & $1650 \mathrm{~s}$ & 15000 & 19.75 & 759 \\
Beck & $1660 \mathrm{~s}$ & 6000 & 5 & 1200 \\
Dun & $1720 \mathrm{~s}$ & 1400 & 1 & 1400 \\
Aire & $1730 \mathrm{~s}$ & 24750 & 18 & 1375 \\
Dee & $1720 \mathrm{~s}$ & 26700 & 25 & 1068 \\
Exe & $1740 \mathrm{~s}$ & 56461 & 8 & 7058 \\
great Ouse & $1690 \mathrm{~s}$ & 21000 & 4 & 5250 \\
& $1630 \mathrm{~s}$ & 10000 & 14 & 714 \\
Average & & & & \\
& & 21660 & 16 & 1918
\end{tabular}

Sources: For the Avon, Kennet, Weaver, Douglass, Beck, and Dun rivers see Willan (1964, pp. 66-72). For the Wey and Salwerpe rivers see Bogart (2009). For the Aire and Calder see Wilson (1971, p. 138). For the Great Ouse see Summers (1973, p. 50). For the Dee see the Journals of the House of Commons, 5.3.1743, and for the Exe see the Journals of the Commons, 15.2.1699. The mileage of rivers is taken from Priestly (1969) and Shead (2007). 


\section{References}

Bogart, Dan. (2005). Turnpike Trusts and the Transportation Revolution in Eighteenth Century England. Explorations in Economic History 42, pp. 479-508.

Bogart, Dan. (2009). Did the Glorious Revolution Contribute to the Transport Revolution? Evidence from Investment in Roads and rivers. Working Paper.

Bond, Philip (2009). Contracting in the Presence of Judicial Agency. The B.E. Journal of Theoretical Economics: 9 (Advances), Article 36.

Clark, Greg. (1998). The Charity Commissioners as a Source in English Economic History Research in Economic History, 18, pp. 1-52.

Great Britain. House of Commons. (1833). Report from the Select Committee on House of Commons Officers and Fees. British Parliamentary Papers Vol. XII, 1833.

Great Britain. (1960). Statutes of the Realm. London.

Harris, Ron. (2000). Industrializing English Law: Entrepreneurship and Business Organization, 1720-1844. Cambridge: Cambridge University Press.

Hayek, F. (1960). The Constitution of Liberty. Chicago: University of Chicago Press.

Hoppit, J. (1997). Failed Legislation, 1660-1800. London.

Klerman, Daniel, and Paul Mahoney. Legal Origin. Journal of Comparative Economics 35, pp. 278-293.

La Porta, Rafael, Florencio Lopez-de-Silanes, Cristian Pop-Eleches, and Andrei Shleifer. (2004). Judicial Checks and Balances. Journal of Political Economy 112, pp. 445-470.

Leunig, Timothy. (2006). Time is Money: A Re-Assessment of the Passenger Social Savings from Victorian British Railways. The Journal of Economic History 66, pp. 635-673.

Kostal, R. W. (1994). Law and English Railway Capitalism, 1825-1875.Oxford: Clarendon Press.

Mahoney, Paul. (2001).The Common Law and Economic Growth: Hayek Might be Right. The Journal of Legal Studies. 30, pp. 503-525.

Neal, Larry. (1990). The Rise of Financial Capitalism: International Capital Markets in the Age of Reason. Cambridge: Cambridge University Press. 
North, Douglass. C. and Barry Weingast. (1989). Constitutions and Commitment: The Evolution of Institutions Governing Public Choice in Seventeenth-Century England. The Journal of Economic History 49, pp. 803-832.

Pollins, Harold (1952). A Note on Railway Construction Costs 1825-1850. Economica 19, pp. 395-407.

Priestly, Joseph. (1969). Priestly's Navigable Rivers and Canals. London: David and Charles.

Roe, Mark. (2007). Juries and the Political Economy of Legal Origin. Journal of Comparative Economics 35, pp. 294-308.

Rosenthal, Jean-Laurent (1992). Fruits of the Revolution: Property Rights, Litigation, and French Agriculture, 1700-1860. Cambridge: Cambridge University Press.

Shead, Jim. (2007). “UK Waterways Locks and Distances.” http://www.jimshead.com/waterways/index.php.” (last updated August, 2007).

Summers, Dorothy. (1973). The Great Ouse: The History of a River Navigation. London: David \& Charles.

Willan, Thomas S. (1964). River Navigation in England, 1600-1750. London: Frank Cass \& Co.

Wilson, R. G. (1969). Transport Dues as Indices of Economic Growth, 1775-1820. Economic History Review 19, pp. 110-123.

Wilson, R. G. (1971). Gentleman Merchants: The Merchant Community in Leeds. New York: Augustus M. Kelley. 